\title{
Buddhism between Asia and Europe: The Concept of Mindfulness through a Historical Lens
}

\author{
Tamara DITRICH*
}

\begin{abstract}
Since the beginning of the twentieth century mindfulness has been positioned at the core of modern Buddhism and viewed by many modern interpreters as an essential component of Buddhist doctrine and practices. More recently, the practice of mindfulness has become rapidly popularised, radically secularised and removed from its Buddhist context, employed mainly as a therapeutic tool or applied for the enhancement of well-being. This paper examines the concept of mindfulness using an historical lens, aiming to identify some of the main parameters and consequent implications involved in the changes and developments of this Buddhist contemplative method-from its early beginnings over 2,500 years ago to the present day. Special attention is given to the historical developments in the colonial period, when various Buddhist traditions encountered the main European discourses of the time, resulting in the birth of modern Buddhism. In this period, particularly in Burma, meditation was positioned at the centre of Buddhist teachings and thus provided the grounds and conditions for the subsequent popularisation and secularisation of mindfulness in the late twentieth century. Through an examination of the concept of mindfulness through history, the paper explores whether a critical awareness of historical facts provides a better understanding of the current ubiquity of mindfulness practices worldwide. In addition, mindfulness has recently become an object of scientific research and, hence, it is important to investigate it in different contexts and discourses throughout history, and understand the implications of various definitions, interpretations and applications of mindfulness for the development of modern research approaches and methodologies.
\end{abstract}

Keywords: Buddhist meditation, mindfulness, Buddhist history, modern Buddhism

\section{Izvleček}

Od začetka 20. stoletja je bila čuječnost postavljena v sam center modernega budizma in je pogosto predstavljena kot bistvo budistične doktrine in prakse. V zadnjih desetletjih se čuječnost izjemno hitro širi po vsem svetu, vendar predvsem kot sekularna metoda, popolnoma izvzeta iz svojega izvornega budističnega konteksta, ter ima terapevtsko vlogo ali pa je sredstvo za izboljšanje počutja. Prispevek raziskuje koncept čuječnosti skozi zgodovino

Tamara, DITRICH, Research Fellow, University of Ljubljana,

Nan Tien Institute and University of Sydney.

t.ditrich[at]gmail.com

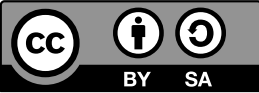


in poskuša identificirati glavne parametre, ki so pogojevali spremembe v konceptualizaciji in aplikacijah te starodavne budistične kontemplacijske metode - od njenih začetkov pred več kot 2500 leti pa do danes. Posebna pozornost je namenjena zgodovinskemu obdobju kolonizacije, ko so se budistične tradicije soočile s takratnimi evropskimi diskurzi, in kako je to srečanje porodilo moderni budizem. $V$ kolonialnem obdobju, predvsem v Burmi, so se na kolonizacijo odzvali s konstruktom modernega budizma, ki je meditacijo postavil $\mathrm{v}$ središče budizma in tako ustvaril pogoje za njeno popularizacijo in kasnejšo sekularizacijo, ki smo ji priča od zadnje polovice 20. stoletja. Prek predstavitve zgodovinskega razvoja čuječnosti prispevek raziskuje, kako lahko kritično zavedanje zgodovinskih pogojev in okoliščin doprinese $\mathrm{k}$ boljšemu razumevanju dandanašnje izjemne širitve aplikacij čuječnosti po svetu. V 21. stoletju je čuječnost postala tudi predmet znanstvenih raziskav, pri čemer so se odprla številna vprašanja $\mathrm{v}$ zvezi $\mathrm{z}$ njeno konceptualizacijo, interpretacijo in aplikacijo. Prispevek ugotavlja, da lahko poznavanje konceptualizacije in vloge čuječnosti $\mathrm{v}$ različnih zgodovinskih kontekstih in diskurzih doprinese $\mathrm{k}$ razvoju pristopov in metod pri znanstvenih raziskavah.

Ključne besede: budistična meditacija, čuječnost, budistična zgodovina, moderni budizem

\section{Introduction}

The Buddhist concept of mindfulness has a long history of over 2,500 years. The earliest textual records come from ancient Indian Buddhism, where it is situated as one of the central components of Buddhist praxis, aiming at spiritual liberation. With the spread of Buddhism across the Indian subcontinent and later on in most parts of Asia, the concept and practice of mindfulness remained, though sometimes positioned at the background, integrated within the doctrinal discourses and praxes of all major Buddhist traditions. New developments in the colonial period in Asia (approximately in the period from the 1870s to the 1950s) underpinned the emergence of new foci in Buddhism, including positioning mindfulness at the forefront of the Buddhist praxis. This emphasis on mindfulness and its popularisation in the colonial period provided grounds for the consequent spread of mindfulness practice across the world, and its eventual secularisation. In contemporary secular contexts it is primarily viewed as a psycho-therapeutic method or one among the tools for promoting enhanced wellbeing, increased contentment, productivity, and enjoyment of life. In conjunction with the recent new applications of mindfulness, new interpretations have developed that view its roles and functions in radically new ways, unprecedented in the history of Buddhism. Since the late 1980s, and particularly in the last decade, research on mindfulness has been growing rapidly, as evidenced by the exponential growth of research publications (AMRA 2015). 
The increasing ubiquity of mindfulness applications worldwide raises many questions, such as: what social, cultural and historical conditions and circumstances have been involved to allow and provide for this ancient Indian method of contemplation, which was presumably practised only by (relatively few) recluses, ascetics and monastics of ancient India, to become a global phenomenon, applied today in a wide spectrum of social contexts such as psychotherapy, schools, prisons, corporations, wellness industries, and even military institutions? How is mindfulness understood and interpreted in modern secular environments in comparison to its traditional positioning within the Buddhist discourse? Are there substantial differences in the conceptualisation and methods of mindfulness between the two discourses and, if so, how did they evolve? What conditions contributed to the modifications in the presentations of mindfulness to allow it to become a marketable commodity in today's global markets? Which specific cultural, historical, and social parameters have been involved in the reinterpretations of mindfulness through its history, from the ascetic practices of ancient India to its applications in the modern world?

This article discusses how an investigation of the history of mindfulness within various historical contexts may proffer some directions and insights in addressing the above questions. With this aim, the main historical periods that conditioned major shifts in understanding of mindfulness are investigated. Firstly, the paper discusses the origins of mindfulness in the context of ancient Indian history, drawing from the textual sources of the Theravāda Buddhist Canon, traditionally positioned as containing material from the fifth century BCE onwards. Secondly, the paper explores the colonial period, when the first attempts were made at building bridges between Europe and Asia; it focuses especially on the events in Burma, leading to the emergence of modern Buddhism, which established meditation, and mindfulness in particular, at its very centre, viewing it as an essential component of Buddhist doctrines and practices. Thirdly, the article discusses the postcolonial period in which modern Buddhism has become a global religion, resulting in the popularisation and later on secularisation of mindfulness. Some of the main issues involved in the process of the transplantation of a single concept such as mindfulness from ancient Indian discourses into modern European ones are identified.

\section{Early Beginnings in Ancient India}

As evidenced by textual sources, the roots of mindfulness reach far back into ancient India, in the middle of the first millennium BCE, when major Indian philosophical and religious traditions seem to have emerged. This was the so-called Axial Age, a period of cultural transformation of several ancient civilisations where diverse and 
innovative religious movements occurred, sharing many commonalities among them such as the ideas of transcendence, relativity of social realities, and attempts at universalization of ethics (Bellah and Joas 2012). In that period in India, a spectrum of new ideas, religious movements, sciences and philosophies were systematically presented although most of them seem to have been, at least to some extent, a continuation, a new articulation or modification of the pre-existing religious movements.

Textual sources inform that the religious map of pre-Buddhist India included a rich spectrum of religious movements, which may be represented by two main traditions, i.e., the dominant Vedic and non-orthodox ascetic movements, with more or less continuous tension between the two, but also an encounter from which creative responses, new ideas, and movements surfaced in different historical periods (an example par excellence of such an integration is arguably the most popular Hindu text, the Bhagavadgitā). The Vedic tradition, the religion of the dominant élites, had its beginnings probably in the middle of the second millennium BCE (Witzel 1997,263). As evidenced by textual sources, this tradition had been developing a large body of texts, commentaries, and complex practices for about thousand years before Buddhism emerged. Vedic religion was mythical and ritualistic, initially centred around sacrificial rituals and magic practices; however, it also gradually assimilated, reinterpreted and integrated many ascetic ideas and movements (Harvey 2013, 8-14). Historical information about the pre-Buddhist, non-orthodox movement (Sanskrit śramaṇa, Pāli samaṇa) is scarce; it can be inferred from Brahmanical sources but the main information is drawn from early Buddhist texts (Bronkhorst 2000, 78-127; Jaini 2001, 47-96).

Buddhism seems to have emerged together with other contemporary ascetic movements such as Jainism around the fifth century BCE. It shares major foci with other ascetic traditions, centring on the ideas of karma, rebirth, transcendence (of the human world and the entire cosmos), ascetic practices, including mental training, and the development of philosophical ideas and theoretical representations to justify particular ascetic movements (Gethin 1998, 10-11). The ascetic traditions view rebirth as undesirable, as suffering, and thus essentially question the order of the world itself: the highest goal is no longer to flourish in human life, as the Vedic tradition would aim for, but to transcend it (Taylor 2012, 335). Hence, the aim of Buddhism is transcendence, awakening (bodhi), a profound transformation of human consciousness, reached through ethical and meditative training, and, for the monastics, renunciation of worldly life, which means disconnecting an individual from the existing social structure.

The historical background of the beginnings of Buddhism is succinctly summarised by Obeyesekere $(2012,139)$ : it was the time of social and economic changes in India 
with the increasing expansion and power of major kingdoms such as Kosala and Magadha; the emergence of new cities; development of trade and expansion of trading routes; modifications of the social structure with the emergence of a new class of traders acting as patrons of new religious movements. All these changes would bring about disruptions and dislocations of traditional life, and at the same time allow broader communication and exchange of ideas. In this context, the pre-existing values may have been questioned and new solutions to the problems of existence proposed. Political and economic expansion would be reflected in the expansion and universalisation of concepts and ideas as exemplified by the Buddhist proposition of transcendence or the universality of dharma or ethics (Obeyesekere 2012, 140). Although it seems plausible that the socio-economic changes of the time allowed for more rapid expansion of new ideas and religious practices, it would be more difficult to directly link the new socio-political situation to the premises of the Buddhist discourse itself. The foundations or at least major components of the Buddhist doctrine may be identified in the pre-existing religious ideas and movements of India; for example, the universalizing of transcendence or ethics is evidenced already in the later Vedic tradition, and meditation practices are recorded in the pre-Buddhist Upanisads. Furthermore, as argued by Bronkhorst (2000), a large segment of meditation practices in Buddhism may originate from other pre-existing ascetic traditions of India. However, the particular historical circumstances in the middle of the first millennium BCE brought about the conditions for the articulation and great expansion of Buddhist ideas and practices, and formation of a systematic theoretical formulation of the early Buddhist discourse in the Abbidhamma literature, which is one of the important foundations for later philosophical developments. It has to be noted that Buddhist philosophical ideas and meditative praxes emerged mainly from the individuals or monastic communities that were initially situated outside the political centres, engaging only with a minority of the population.

Along with the shared context of the ascetic discourses of the time, Buddhism also provides its own, specific approaches, practices, and theoretical representations; among these, mindfulness (Pāli sati, Sanskrit smrti) has a prominent position, having been for the first time presented, explained, and closely integrated into the entire Buddhist exegetical project. Sati is situated in the fundamental structure of the four truths, outlined already in the Buddha's first sermon, the Dhammacakkappavattanasutta (Bodhi 2000, 1843-1847). ${ }^{1}$ This sutta sums up the early Buddhist doctrine about suffering and liberation from it, by incorporating ethical,

1 Interpretations of mindfulness that have evolved in modern Buddhism very frequently refer back to Theravāda sources, hence this overview of the roots of mindfulness draws from the Theravāda Buddhist canon and consequently, the technical terms for mindfulness and the related concepts are given (in brackets) in Pāli. 
soteriological and pragmatic aspects of the teachings (Sumedho 2003). The four truths comprise: (1) the diagnosis of the disease: the conditioned interrelated phenomena that constitute life are unsatisfactory, subject to suffering (dukkha); (2) the origin of the disease: suffering $(d u k k h a)$ is caused by craving (taniha $)$ which is linked to ignorance (avijja) ; (3) the cure: complete extinction (nibbāna) of craving, ignorance, and aversion; (4) the medicine as the way to perfect health: the eightfold path, comprising ethical training, meditation, and wisdom. Mindfulness is an integral part of the eightfold path, intrinsically linked to all the other components: as right mindfulness (samma sati) it is central in cultivation of wholesome mental states (kusala dhammā) and the arising of wisdom (pañ $\tilde{n} \bar{a})$, which is presented as an understanding of the nature of all physical and mental processes and phenomena (i.e. impermanence, non-satisfactoriness, and non-self) and thus a pivotal condition for liberation from ignorance, for realisation of nibbāna. According to the Abhidhamma, mindfulness and wisdom are wholesome mental components (kusalä dhammā), occurring only in ethical mental states, which are presented as those free from greed, aversion, and delusion (Bodhi 1993, 85-90). To summarise, mindfulness is seen to protect the mind from reacting with desire and aversion; to condition development of an understanding as to whether mental states are wholesome or not; and, together with clear comprehension, to establish the grounds for wisdom to evolve, which, in turn, is an indispensable condition for spiritual liberation (Ditrich 2015, 3).

There are several different concepts in Pāli related to mindfulness that are often lost in linguistic and cultural translation, due to the lack of equivalent concepts and appropriate terminology in modern European languages and discourses (Gethin 2013). Mindfulness is often understood as a synonym for attention (or awareness) although the Buddhist sources clearly distinguish these two terms. The Pāli term manasikāra, which is usually rendered into English as "attention" or "awareness", is described in the Buddhist sources as a mental factor (cetasika) that functions as the bare cognition of an object before it is recognized, identified, and conceptualized (Bodhi 1993, 81), and can be associated with ethical or non-ethical mental states. On the other hand, mindfulness (sati) is a mental factor, described in the Abhidhamma to be able to occur only with "wholesome" (kusala) mental states; it is often linked with wise attention (yoniso manasikāra), i.e., attention arising together with understanding of what is wholesome and what not, and which facilitates the development of wisdom (Anālayo 2006, 58). Mindfulness as a constituent of the eightfold path, leading to liberation from suffering, is called "right mindfulness" (sammā sati); it is comprised of mindfulness (sati), freedom from desire and aversion (vinneya abhijjhädomanassa), clear comprehension (sampajāna) and diligence (átāp') (Anālayo 2006, 49). 
To summarise: within the broader framework of ancient Indian religious and philosophical discourses, Buddhism seeks transcendence, achieved through the eightfold path, encompassing marked pragmatic and ethical components. The goal of meditation practice, which includes mindfulness, is liberation from suffering, in Pāli terminology bodhi, frequently translated into English as "enlightenment"; however, a more appropriate translation would be "awakening" - awakening from (the nightmares of) delusions, cravings, and aversions. Mindfulness is thus a component of a larger soteriological framework of early Buddhism that emerged within ancient Indian religious discourses of the time and is implicitly related to them. As outlined above, this broader framework defines what mindfulness is and what its aims at; how it functions in the broader context of Buddhist discourse within the specific historical, social and cultural circumstances of the time; it informs how mindfulness is conceptualised and describes or prescribes the methods of practice, the processes involved, and the expected outcomes; it also provides extensive "cognitive maps", especially in the Abhidhamma teachings, which are always presented through an ethical lens, and universalizes the structure of human consciousness through an analysis of its constituents and the processes involved. It has to be reiterated that mindfulness is always one component within the overall ethical and soteriological framework of Buddhist discourse, and cannot be singled out as a meditation method, leading on its own to liberation from suffering.

\section{Colonial Period: the Birth of Modern Buddhism}

The term "modern Buddhism", coined by Lopez (2002, ix-xliii), is used as an umbrella term for a wide spectrum of doctrines, philosophies, rituals, and practices that have emerged over the last 150 years. Its beginnings are situated in the late nineteenth century, the time of new developments in Buddhism that occurred as a response to the colonisation of Asia and the consequent encounters between Buddhist traditions and European discourses of the time. Modern Buddhism was reinvented by both Westerners and Asian Buddhists, aiming to represent Buddhism as a world religion equal to Christianity, as well as a philosophical system compatible with European ideas of science and rationalism (Lopez 2002, xiii). As outlined well by McMahan (2008, 67-73), in the encounter with Christianity, particularly Protestantism in colonised Ceylon and Burma, Buddhism responded by: diminishing the traditionally central role of the Sangha and the increased involvement of and leadership from the laity, thus reflecting the anti-clericism of Protestantism; positioning the early Canonical texts as the source of "true" or "original" Buddhism, while largely disregarding the living Buddhist traditions of the time; situating meditation at the very centre of Buddhism, perceiving it to be 
a private, subjective, individualised practise and experience, reflecting a Protestant aim for an individual to relate directly to and experience God without priestly intermediaries.

Another significant parameter in the evolvement of modern Buddhism was the meeting of Buddhist societies with European science and rationalism, which in turn had stemmed from the ideas of the European Enlightenment, with a strong emphasis on empiricism, reason, science, individualism, universalism, freedom, rejection of religious orthodoxy-to name a few (Lopez 2002, xi-xii; Scharf 1995, 252). Consequently, modern Buddhism would reject those facets considered incompatible with science and the non-rational, such as image worship, rituals, and magical practices witnessed in the colonial period, and would instead seek to return Buddhism to its original texts, representing them as a complete philosophical and psychological system based on reason (McMahan 2008, 65-67). The representation of Buddhism as a "scientific" religion laid the ground for the interpretation of meditation as a rational enquiry and thus set the scene for scientific research of meditation, mindfulness in particular, in the past few decades, viewing it as an object of science as well as science in itself (e.g., Wallace 2007).

The colonial period was also the time of European Romanticism, which evolved as a critique of rationalisation, secularisation, and materialism, and projected spirituality and mysticism onto the East, pursuing the sacred through spiritual experiences as a form of self-expression and personal fulfilment. These facets of Romanticism played a major role in positioning meditative experience at the forefront in modern Buddhism, frequently viewing it at the very core of Buddhism (Scharf 1995). An example of Romanticism, in confluence with rationality, is the Theosophical Society, established in 1875 in New York, which was instrumental in the development of modern Buddhism: it created one of the earliest bridges between European and Buddhist religious discourses by merging an eclectic Western esotericism and mysticism with Hindu and Buddhist doctrines (Lopez 2002, xiv-xvi; Harvey 2013, 420-1). Aiming to highlight the essence of all religions and to construct a scientific universal religion, it was instrumental in what Theosophists believed to be the restoration of "original" Buddhism, an "essential core", largely drawn from the earliest textual records in Pāli, grounded in the four truths, the doctrine of non-self, dependent origination, and a strong emphasis on meditation as the essence of Buddhist praxis. These aims are represented especially by Colonel Olcott, one of the founders of the society, in his Buddhist Catechism (1881), where he outlines the "essential" doctrine of Buddhism, which he proposes to be "universal" for all Buddhist traditions, largely based the Theravāda tradition of Ceylon, believed to be the most authentic version of Buddhism (McMahan 2008, 97-101; Lopez 2002, xviii). 
Among the European discourses emerging during the colonial period, psychology has had one of the most significant long-term impacts on the interpretation of Buddhism and particularly meditation, by attributing new meanings to Buddhism through a psychological lens: cosmology has become psychology, gods are facets of the human mind, cosmological realms are mental states, and later on, in the postcolonial period, Zen is presented as a form of psychoanalysis (McMahan 2008, 48). Meditation, formerly a part of the complex Buddhist path, is now represented as a private psychological experience or mental event (Scharf 1995, 68). These developments have facilitated a new understanding of the aim of meditation: the traditional pursuit of freedom from rebirth in various undesirable realms and the ultimate liberation from rebirth is replaced by the aim of liberating an individual from negative, conflicting mental states (McMahan 2008, 52-57). This shift was a precondition for the emergence, in the last few decades, of clinical applications of mindfulness as a therapeutic tool, viewing it entirely in psychological terms.

Apart from the main parameters involved in the evolution of modern Buddhism outlined above, particular developments in Burma during the colonial period greatly contributed to the central positioning of meditation and its rapid expansion on a mass scale, unprecedented in the history of Buddhism. Burma was gradually colonised in the nineteenth century, over three Anglo-Burmese wars (between 1824 and 1885), with the final annexation of the entire country to the British Empire in 1885. Before annexation, the last king Mindon of upper Burma and his court responded to the colonial threat and political instability by trying to strengthen their kingdom through increased support of Buddhism with what was considered then meritorious actions such as the strong support of monasteries, protection of the Sangha, organisation and running of the Fifth Buddhist council in 1871, and the inscribing of the entire Pāli Canon on 729 large marble slabs in Mandalay, each shrined in a pagoda (Ahmar 1994; Bolée 1968). In this period, the Burmese educated elite around the court also encountered European modernity, and showed great interest particularly in science and technology and consequently, started to introduce innovations such as the introduction of printing press. Western science was viewed by them as complementary to Buddhism, and they endeavoured to interpret it to be compatible with Buddhism, providing additional understanding of Buddhism; they situated science within the Buddhist framework and its aims (Braun 2013, 19-28).

Following annexation into the British Empire, the Sangha, no longer under the patronage of the kings, turned to the lay population for support in an attempt to protect Buddhism in Burma. In this process Buddhism was reformulated, reconstituted and re-evaluated by positioning at its forefront two domains, traditionally 
assigned to the monastics, i.e., the study of the textual tradition, particularly the Abhidhamma, and meditation, as the way of practicing Buddhism for the lay population (Braun 2013, 150-5). Although in the pre-colonial period individual monks would practise meditation, the lay population did not do so, and awakening was perceived by both monastics and the laity as a very remote possibility in distant future lives. The foci of Buddhist practice for the laity throughout Buddhist history seem to have been predominantly devotion, development of generosity and virtue and the generation of merit. In the colonial period a major shift occurred: meditation began to be practised by lay people on a massive scale in everyday life, and awakening presented an actual possibility to be attained "in this very life", as frequently stated by Ledi Sayadaw $(1999,160 ; 194)$, one of the most influential figures in the development of modern Buddhism in Burma.

Ledi Sayadaw (1846-1923) was a very significant Buddhist scholar, a prolific writer, a charismatic speaker, and meditation master, who was instrumental in the secularisation, popularisation and expansion of meditation and mindfulness, both for the Sangha and the laity. He popularized the study of Buddhism, especially the Abhidhamma, viewing these texts as the essential foundation for meditation practice, particularly insight meditation (vipassana $\bar{a}$. One of Ledi's teachers from the pre-colonial period was U Hpo Hlaing (1830-1883), King Mindon's minister, who was interested in European science and aimed to link it with the Abhidham$m a$. Following his teacher, Ledi Sayadaw considered science to be in agreement with Buddhism, whereas European scholars of the time viewed this relationship the other way around (Braun 2013, 32). In his endeavour to protect Buddhism, and in creative response to colonialism by drawing from and newly representing their own Buddhist heritage, Ledi and his followers turned to the lay population for the continuation of Buddhist teachings through a new emphasis on meditation which was to be informed by and embedded in the knowledge of Buddhist teachings, particularly the Abhidhamma. Mindfulness was newly presented by Ledi and his followers as the most appropriate method of meditation for the lay population, to be practised outside the monastic environment; he stated that a lay person who meditated could be called a monk (ibid., 122). He wrote numerous works on Buddhism in Burmese, in a language and style accessible for lay people, which became, through the use of print, extremely popular (ibid., 131).

Insight meditation (vipassanā) which is largely founded on the practise of mindfulness thus became in Burma, and later on in other Theravāda Buddhist countries, a primary practise of modern Buddhism. Traditionally, meditation comprises two interlinked practices, i.e. samatha (a practice emphasizing the development of concentration but including also mindfulness and other factors), which is usually practised first, followed by vipassana (based on the development of mindfulness 
and cultivation of other mental components) (Sujato 2005). The two methods are presented in early Buddhism as constituents of a larger soteriological structure, involving a variety of meditative methods, which would presumably require extensive practise. The Pāli texts also provide detailed analyses of the "types" of consciousness in conjunction with its mental factors and processes involved in the development of concentration, mindfulness, and wisdom. Modern Buddhism, with Ledi and his followers, gave pre-eminence to vipassana, since the practice of samatha was considered too demanding for lay people, requiring lengthy practise, preferably in solitude. Mindfulness was recommended to be practiced in everyday activities, in the mundane domain (Ledi 1999, 28), while still embedded in and informed by the Buddhist teachings. Inevitably, this shift resulted in simplification of the method itself and impacted on the process of meditation itself, its outcomes, and its interpretations. The time dedicated to formal meditation was significantly shortened, and the expectations of quick results notably heightened: the possibility of awakening "in this very life", reiterated by Ledi Sayadaw, was a few decades later translated by another influential teacher, Mahasi Sayadaw, into the possibility of experiencing the first stage of awakening (sotäpatti) even in a few weeks (Scharf 1995, 256).

Mindfulness is not seen by Ledi as the sole component on the Buddhist path but rather as one component though a very important one. Ledi perceived meditation as an individual pursuit; it was only his disciples who later on established meditation centres and thus, for the first time, created domains for collective lay practice (Braun 2013, 144) with far reaching impact within Burma and in the contemporary world. Ledi Sayadaw's lineage of influential disciples included Saya Thetgyi (1893-1945), one of the first lay teachers of meditation, and his disciple U Ba Khin (1899-1971) who modified and simplified meditation methods for lay people. Further down this particular lineage was Goenka (1924-2015), who was instrumental in popularising vipassan $\bar{a}$ worldwide in the format of a tenday course. Another famous teacher of the colonial period was Mahasi Sayadaw (1904-1982), who became the most popular teacher in Burma (Scharf 1995, 255); his method of mindfulness practice spread worldwide and constitutes a large component of today's contemporary mindfulness applications in secular contexts around the globe.

Modern Buddhism in Burma adjusted, simplified and reinvented mindfulness along with popularising meditation amongst the Burmese laity; yet, it still retained its position within Buddhist discourse. However, the new foci, and especially mass meditation practice amongst the laity and the consequent simplification of the methods with the assurance of quick results prepared the grounds for further popularisation, firstly from Buddhist monastics to Buddhist lay practitioners, and 
then to the new stage-i.e. the modern secular interpretations and applications of mindfulness.

\section{Postcolonial Period: Popularisation and Secularisation of Mindfulness}

In the postcolonial period, the two prominent lineages of vipassana meditation from Burma, propagated by Mahasi Sayadaw and U Ba Khin respectively, gradually spread across other Theravāda Buddhist countries and, from the 1970s onward, worldwide. Meditation courses taught in the US and Europe were initially based on the Burmese methods of mindfulness practice, however, already at early stages they started to draw from and integrate other Buddhist traditions as well as non-Buddhist spiritual practices (Braun 2013, 162-4). Importantly, new interpretations of mindfulness developed that perceived it mainly as a form of awareness training, with the benefits of enhanced psychological wellbeing. The focus on liberation in this life, already articulated in colonial Burma, was taken further: it conditioned the new perception of mindfulness as a tool for self-improvement in therapeutic contexts. Consequently, suffering, which is viewed in traditional Buddhism as an intrinsic feature of birth, ageing, sickness, and death, is viewed in modern Buddhism as caused either by poverty and social injustice as interpreted in engaged Buddhism (King 2000) or, more frequently in therapeutic approaches, by personal circumstances and events in an individual's life; hence, meditation aims to improve societal life as well as personal life.

Since the 1980s, mindfulness has been increasingly applied in various forms of psychotherapy such as therapy for anxiety disorders, depression, pain management, relationship counselling, etc. Kabat-Zinn has been particularly instrumental in proliferating mindfulness in therapies with his initial program "Mindfulness-Based Stress Reduction" (MBSR) in the 1970s; since then this programme and many others have been developed and expanded worldwide. The proliferation of mindfulness has been followed by rapidly growing research, indicating the benefits of mindfulness-based therapies (e.g. Eifert and Forsyth 2005) and their positive effects on the brain (Fox et al. 2014). In these new domains mindfulness is often presented as bare awareness of or attention to the present moment, without interference, in a non-judging way (Kabat-Zinn 2003, 145). ${ }^{2}$ Nānapononika's book The Heart of Buddhist Meditation (1962) largely contributed to the rendition of the term mindfulness as "bare attention", which in turn strongly influenced the consequent definitions of mindfulness, as pointed out by Gethin $(2011,267)$.

2 The attribute "non-judging" does not stem from Buddhist traditions; it was coined, as far as I am aware, by Kornfield (2012, 2). 
Mindfulness is perceived to be a therapeutic tool for a wide spectrum of problems and disorders as well as for achieving an enhanced ability to enjoy pleasures of life (Baer 2006, 10). These presentations are significantly different from the Buddhist aim of mindfulness, which seeks freedom from desire or attachment to pleasure.

In the last two decades, the conceptualisation and application of mindfulness have been responding in new ways to new circumstances-such as global capitalist markets, consumerism, new modes of communication through the expansion of media and virtual networks-by transforming mindfulness into a marketable commodity. Secularised mindfulness applications seem to be currently developing into two different, yet closely related directions. On the one hand, it is further applied in an expanding spectrum of therapeutic contexts, specifically in various types of psychotherapy, in which it has retained one of the Buddhist aims of meditation-release from suffering. On the other hand, mindfulness is also increasingly applied in order to enhance well-being in various work environments, such as corporations or even the military, aiming to increase productivity, adaptability, and success rates, and improve work performance, leadership, and decision making - to name a few. Here mindfulness has received radically new meanings, often devoid of ethical considerations as exemplified in the military context or in the corporate world, where it can be potentially misappropriated as a means for maintaining the status quo in unacceptable work environments, aiming to maintain power and increase profits (Purser and Millilo 2015). The new aims of secularised mindfulness reflect consumerist social values such as the pursuit of increased enjoyment, self-satisfaction, self-maintenance, or personal fulfilment, in stark contrast to the understanding of mindfulness in the Buddhist paradigm, both in ancient India and in the more recent colonial period, where the pursuit of happiness and increased enjoyment are not the core aims, though they may be side effects of meditation practice. The goals of Buddhist meditation are clearly situated in ethical and soteriological domains (Ditrich 2013).

Increased applications of mindfulness have triggered, especially in the last decade, rapidly growing research, focusing mainly on the effects of its applications. Mindfulness has been researched mainly through the methodological tools of social and medical sciences, particularly psychology, applying quantitative and, less frequently, qualitative methods. A recent meta-analysis of the research of mindfulness, based on 595 scholarly studies $^{3}$ (Sedlmeier et al. 2012), concludes that most studies of mindfulness have serious methodological problems because they were conducted without sufficient theoretical background in a largely atheoretical

3 Initially 595 scholarly studies were identified, but almost $75 \%$ were excluded from the overview due to methodological problems. 
manner. This analysis suggests that the focus of research should be on how and why meditation works rather than on the current main preoccupation with the question of whether it works. The study recommends the development of more precise theories and measurement devices for future research, which should aim to identify the components of meditation practice from which predictions could be drawn about its effects. With this aim in mind, it may be proposed here that a systematic investigation of the extent to which current theoretical models could be informed by the Buddhist contemplative traditions from which mindfulness stems in the first place would contribute to the scientific research of mindfulness. Such an investigation may also represent an attempt to construct a bridge between the ancient Buddhist and modern scientific discourses, without appropriating either.

\section{Conclusion}

Although meditation methods have been very adaptable throughout Buddhist history, the recent extraction of mindfulness from its Buddhist roots have resulted in its unprecedented ubiquity, being increasingly perceived and used as one of the innumerable new commodities in the global spiritual and wellness markets. This paper has discussed how these radical shifts in understanding mindfulness were historically conditioned, especially through the events involved in the evolution of modern Buddhism as response to colonialism and the encounter with European modernism. As far as mindfulness is concerned, the historical changes in colonial Burma may be singled out as highly significant, particularly the new positioning of two important components of Buddhist discourse: firstly, situating meditation, and especially mindfulness, at the forefront of Buddhism; secondly and more importantly, positioning the practise of mindfulness into a secular domain through its popularisation amongst the laity on a mass scale. Thus, for the first time in Buddhist history, the majority of practitioners of mindfulness meditation were lay people, practising mindfulness in everyday worldly life; however, the practice remained strictly within traditional Buddhist discourse, to be practised in conjunction with the cultivation of virtue, generosity and the generation of merit, all building towards a transcendental aim. The shifts in colonial Burma prepared the grounds for the eventual popularisation of mindfulness worldwide in the post-colonial period, and its eventual secularisation within new discourses and domains of practice.

The new constructs of mindfulness raise dilemmas and require closer examination. As pointed out by Gethin $(2011,268-9)$, the removal of mindfulness from 
its Buddhist context may be seen as a misrepresentation of traditional Buddhist meditation; or alternatively as the extrication of essential components of mindfulness while shedding an unnecessary traditional context; or as a modern integration of essential and useful components of Buddhist meditation with modern science. Furthermore, it may be noted that the various conceptualisations of mindfulness, the methods of its practice, and the processes involved may have immediate implications for research approaches and outcomes. Since mindfulness has become an object of scientific research, it is even more important to understand mindfulness in different historical contexts and paradigms that have implications for its definitions, methods of practice, as well as the experiences and expected outcomes from the practice itself, and, consequently, all have an impact on research methods and results. The decontextualized modern construct of mindfulness, used primarily as a tool for achieving improved well-being may limit its potential, as indicated in the Buddhist discourse, for deeper investigation of human consciousness and ethics which today's world needs to address and explore. With this in mind, examination of the evolution of the concept of mindfulness through a critical awareness of historical facts involved in its conceptualisation and praxis in different contexts may serve as a corrective to the modern, prevalently ahistorical, constructs of mindfulness.

\section{References}

Ahmar, Ludu Daw. 1994. The World's Biggest Book. 3rd ed. Mandalay: Kyi Pwa Ye.

AMRA 2015. "Mindfulness Journal Publications by Year, 1980-2014.” AMRA Resources and Services, AMRA Database. Accessed August 5, 2015. https:// goamra.org/resources/.

Anālayo. 2006. Satipațāna: The Direct Path to Realization. Selangor: Buddhist Wisdom Centre.

Baer, Ruth A., ed. 2006. Mindfulness-Based Treatment Approaches: Clinician's Guide to Evidence Base and Applications. Burlington, MA: Academic Press.

Bellah, Robert N, and Hans Joas, eds. 2012. The Axial Age and Its Consequences. Cambridge, Mass. and London: Belknap Press of Harvard University Press.

Bodhi, trans. 1993. Abhidhammattha Sangaha: A Comprehensive Manual of Abhidhamma: Pali Text, Translation and Explanatory Guide. Kandy: Buddhist Publication Society.

Bodhi, trans. 2000. The Connected Discourses of the Buddha: A New Translation of the Samyutta Nikàya. Boston: Wisdom Publications. 
Bolée, W. B. 1968. "Some Less Known Burmese Pali Texts.” In Pratidānam: Indian, Iranian and Indo-European Studies Presented to Franciscus Bernardus Jacobus Kuiper on his Sixtieth Birthday, edited by J.C. Heesterman, G. H. Schokker and V. I. Subramoniam, 493-9. The Hague: Mouton.

Bronkhorst, Johannes. 2000. The Two Traditions of Meditation in Ancient India. Delhi: Motilal Banarsidass.

Ditrich, Tamara. 2013. "Mindfulness in Modern Buddhism: New Approaches and Meanings". In One Dharma: Many Buddhist Traditions: A Festschrift in Memory of K Sri Dhammananda (1919-2006), edited by Benny Liow Woon Khin, 181-90. Petaling Jaya: Buddhist Gem Fellowship.

Eifert, Georg, and John P. Forsyth. 2005. Acceptance and Commitment Therapy for Anxiety Disorders. Oakland, CA: New Harbinger Publications.

Eriksen, Christine, and Tamara Ditrich. 2015. "The Relevance of Mindfulness

Practice for Trauma-exposed Disaster Researchers." Emotion, Space and Society 1-7. http://dx.doi.org/10.1016/j.emospa.2015.07.004.

Fox, Kieran C. R., Savannah Nijeboer, Matthew L. Dixon, James L. Floman, Melissa Ellamil, Samuel P. Rumak, Peter Sedlmeier, and Kalina Christoff. 2014. "Is Meditation Associated with Altered Brain Structure? A Systematic Review and Meta-analysis of Morphometric Neuroimaging in Meditation Practitioners." Neuroscience and Biobehavioral Reviews 43: 48-73. Gethin, Rupert. 1998. The Foundations of Buddhism. Oxford: Oxford University Press.

—. 2011. "On Some Definitions of Mindfulness." Contemporary Buddhism: An Interdisciplinary Journal 12 (1): 263-79.

Gombrich, Richard, and Gananath Obeyesekere. 1988. Buddhism Transformed: Religious Change in Sri Lanka. Princeton: Princeton University Press. Harvey, Peter. 2013. An Introduction to Buddhism. Cambridge: Cambridge University Press.

Jaini, Padmanabh S. "Śramaṇas. (1977) 2001. "Their Conflict with Brāhmanical Society." In Collected Papers on Buddhist Studies, edited by Padmanabh S. Jaini, 47-96. Delhi: Motilal Banarsidass.

Kabat-Zinn, J. 2003. "Mindfulness-Based Interventions in Context: Past, Present, and Future." Clinical Psychology: Science and Practice 10 (2): 144-56. King, Sallie B. 2000. "Thich Nhat Hanh and the Unified Buddhist Church: Nondualism in Action." In Engaged Buddhism in the West, edited by Christopher Queen, 321-63. Somerville, MA: Wisdom Publications. Kornfield, Jack. 2012. Bringing Home the Dharma: Awakening Right Where You Are. Boston and London: Shambala.

Ledi, Sayadaw. 1999. The Manuals of Dhamma. Igatpuri: Vipassana Research Institute. 
McMahan, David L. 2008. The Making of Buddhist Modernism. Oxford: Oxford University Press.

Lopez, Donald. 2002. Modern Buddhism: Readings for the Unenlightened. London: Penguin Books.

Ñānaponika. 1962. The Heart of Buddhist Meditation, London: Rider.

Obeyesekere, Gananath. 2012. “The Buddha's Meditative Trance: Visionary

Knowledge, Aphoristic Thinking, and Axial Age Rationality in Early

Buddhism." In The Axial Age and Its Consequences, edited by Robert N.

Bellah and Hans Joas, 126-45. Cambridge, Mass. and London: Belknap

Press of Harvard University Press.

Olcott, Henry Steel. 1881. A Buddhist Catechism, According to the Canon of the Southern Church. Colombo: Theosophical Society.

Purser, Ronald E., and Joseph Millilo. 2015. "Mindfulness Revisited: A

Buddhist-Based Conceptualisation." Journal of Management Inquiry 24 (1): 3-24.

Scharf, Robert H. 1995. "Buddhist Modernism and the Rhetoric of Meditative Experience." Numen 42: 228-83.

Sedlmeier, Peter, Juliane Eberth, Marcus Schwartz, Doreen Zimmermann, Frederik Haarig, Sonia Jaeger, and Sonja Kunze. 2012. "The Psychological Effects of Meditation: A Meta-Analysis.” American Psychological Association, Psychological Bulletin 138 (6): 1139-71.

Sujato. 2005. A History of Mindfulness: How Insight Worsted Tranquility in the Satipatthana Sutta. Taipei: The Corporate Body of the Buddha Educational Foundation.

Sumedho, Ajahn. 1992. The Four Noble Truths. Hemel Hempstead: Amaravati Publications.

Taylor, Charles. 2012. "What was the Axial Revolution?" In The Axial Age and Its Consequences, edited by Robert N. Bellah, and Hans Joas, 30-46. Cambridge, Mass. and London: Belknap Press of Harvard University Press.

Wallace, Alan. 2007. Contemplative Science: Where Buddhism and Neuroscience Converge. New York: Columbia University Press.

Witzel, Michael, ed. 1997. "The Development of the Vedic Canon and its Schools: The Social and Political Milieu." In Inside the Texts, Beyond the Texts, 257-345. Harvard Oriental Series, Opera Minora, vol. 2. Cambridge, MA: Department of Sanskrit and Indian Studies, Harvard University. 